\title{
Lifetime Prevalence of Self-Reported Work-Related Health Problems Among U.S. Workers — United States, 2018
}

\author{
Hannah Free, $\mathrm{MPH}^{1}$; Matthew R. Groenewold, $\mathrm{PhD}^{1}$; Sara E. Luckhaupt, MD ${ }^{1}$
}

Approximately 2.8 million nonfatal workplace illnesses and injuries were reported in the United States in 2018 (1). Current surveillance methods might underestimate the prevalence of occupational injuries and illnesses $(2,3)$. One way to obtain more information on occupational morbidity is to assess workers' perceptions about whether they have ever experienced health problems related to work (4). Occupational exposures might directly cause, contribute to, exacerbate, or predispose workers to various health problems (work-related health problems). CDC's National Institute for Occupational Safety and Health estimated the lifetime prevalence of self-reported, work-related health problems for the currently employed population overall and stratified by various demographic and job characteristics using data from the 2018 version of the SummerStyles survey. Overall, $35.1 \%$ of employed respondents had ever experienced a work-related health problem $(95 \%$ confidence interval $[\mathrm{CI}]=33.0 \%-37.3 \%)$. The most commonly reported work-related health problem was back pain (19.4\%, 95\% CI $=17.6 \%-21.2 \%)$. Among industries, construction $(48.6 \%, 95 \% \mathrm{CI}=36.54 \%-60.58 \%)$ had the highest prevalence of any work-related health problems. Workplace injury and illness prevention programs are needed to reduce the prevalence of work-related health problems, especially in higher-risk industries.

The SummerStyles survey is one in a series of annual, online surveys conducted by the communications firm Porter Novelli Public Services using panelists recruited using probabilitybased sampling methods. It has been conducted since 1995 and evaluates respondents' beliefs about health topics including self-reported health problems (5). SummerStyles survey data have been demonstrated to be valid for reporting health outcomes when compared with the Behavioral Risk Factor Surveillance System $(5,6)$.
In its 2018 survey, SummerStyles included questions about job characteristics of currently employed adults and whether respondents had experienced various types of work-related health problems. The survey was sent to 5,584 panelists; the response rate was $73.2 \%$. The full survey sample included 4,088 adults aged $\geq 18$ years. Work-related questions were only administered to adult respondents who described themselves as full-time paid employees, part-time paid employees, or self-employed, representing a sample of 2,425 for this analysis. Additional SummerStyles questions collect data on demographic characteristics including age, race, ethnicity, and

\section{INSIDE}

366 Antiretroviral Therapy and Viral Suppression Among Active Duty Service Members with Incident HIV Infection — United States, January 2012-June 2018

371 Nonfatal Drug Overdoses Treated in Emergency Departments — United States, 2016-2017

377 Asymptomatic and Presymptomatic SARS-CoV-2 Infections in Residents of a Long-Term Care Skilled Nursing Facility - King County, Washington, March 2020

382 Preliminary Estimates of the Prevalence of Selected Underlying Health Conditions Among Patients with Coronavirus Disease 2019 - United States, February 12-March 28, 2020

387 Notes from the Field: First Evidence of Locally Acquired Dengue Since 1944 －Guam, 2019

390 QuickStats

Continuing Education examination available at https://www.cdc.gov/mmwr/mmwr_continuingEducation.html

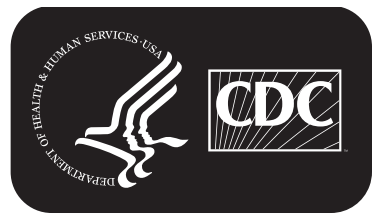

U.S. Department of Health and Human Services Centers for Disease Control and Prevention 
education, as well as employment situation, industry sector, occupation category, and type of work arrangement.

Current workers who had ever experienced work-related health problems were identified by their response to the question "Have you ever experienced any of the following health problems related to any job you have ever held?" Respondents were asked to select all options that applied to them from a list of major categories of injuries and illnesses commonly related to work. This included 1) an injury that required medical treatment, 2) an injury that caused the respondent to miss work, 3) back pain, 4) other joint or muscle problem, 5) asthma or other lung condition, 6) hearing difficulty, 7) cancer, 8) mental health problem (e.g., depression), 9) skin condition, and 10) other health problem not listed. Respondents could also choose the option "no health problems related to work" or "I don't know." Point estimates and 95\% CIs for the weighted* lifetime prevalence of any work-related health problem and specific types of work-related health problems among all workers were calculated. Prevalence ratios (PRs) were calculated to compare the prevalence of any work-related health problem across demographic and job characteristics. Analyses were performed using SAS statistical software (version 9.4; SAS Institute).

The overall lifetime prevalence of any work-related health problem was $35.1 \%$ (Table 1 ). The most commonly reported

\footnotetext{
*Weights were used to match the U.S. Current Population Survey proportions for gender, age, income, race, ethnicity, household size, education, U.S. Census region, and metro status.
}

work-related health problem was back pain, reported by $19.4 \%$ of respondents; $14.7 \%$ of respondents reported a work-related injury that required medical treatment.

The prevalence of any work-related health problem did not vary significantly by sex; however, there was significant variation by age group, education, and race/ethnicity (Table 2 ). Respondents aged 55-64 years reported the highest prevalence of work-related health problems $(41.3 \%)$, nearly twice that of persons aged $18-24$ years $(21.7 \%)$, and prevalences among all age groups except respondents aged $\geq 75$ years were significantly higher than those of respondents aged 18-24 years. Non-Hispanic multiracial respondents had the highest prevalence of work-related health problems (49.1\%). Prevalence among non-Hispanic blacks (39.9\%) was also significantly higher compared with that of non-Hispanic other race respondents (28.2\%). By educational attainment, prevalence was highest (39.2\%) among respondents with less than a high school diploma and lowest $(30.6 \%)$ among those with a bachelor's degree or higher. The prevalence of any work-related health problem did not vary significantly by occupation, or work arrangement, but did vary significantly by industry and employment situation. Compared with the referent (Education) prevalence ratios were significantly higher for the Construction ( $\mathrm{PR}=1.6 ; 95 \% \mathrm{CI}=1.2 \%-2.2 \%)$, Public Safety $(\mathrm{PR}=1.5 ; 95 \% \mathrm{CI}=1.1 \%-2.0 \%)$, Service (excluding Public Safety and Food) $(\mathrm{PR}=1.3 ; 95 \% \mathrm{CI}=1.0 \%-1.7 \%)$ and Social Assistance/Healthcare ( $\mathrm{PR}=1.3 ; 95 \% \mathrm{CI}=1.1 \%-1.7 \%)$ industries. By employment situation, prevalence was

The MMWR series of publications is published by the Center for Surveillance, Epidemiology, and Laboratory Services, Centers for Disease Control and Prevention (CDC), U.S. Department of Health and Human Services, Atlanta, GA 30329-4027.

Suggested citation: [Author names; first three, then et al., if more than six.] [Report title]. MMWR Morb Mortal Wkly Rep 2020;69:[inclusive page numbers].

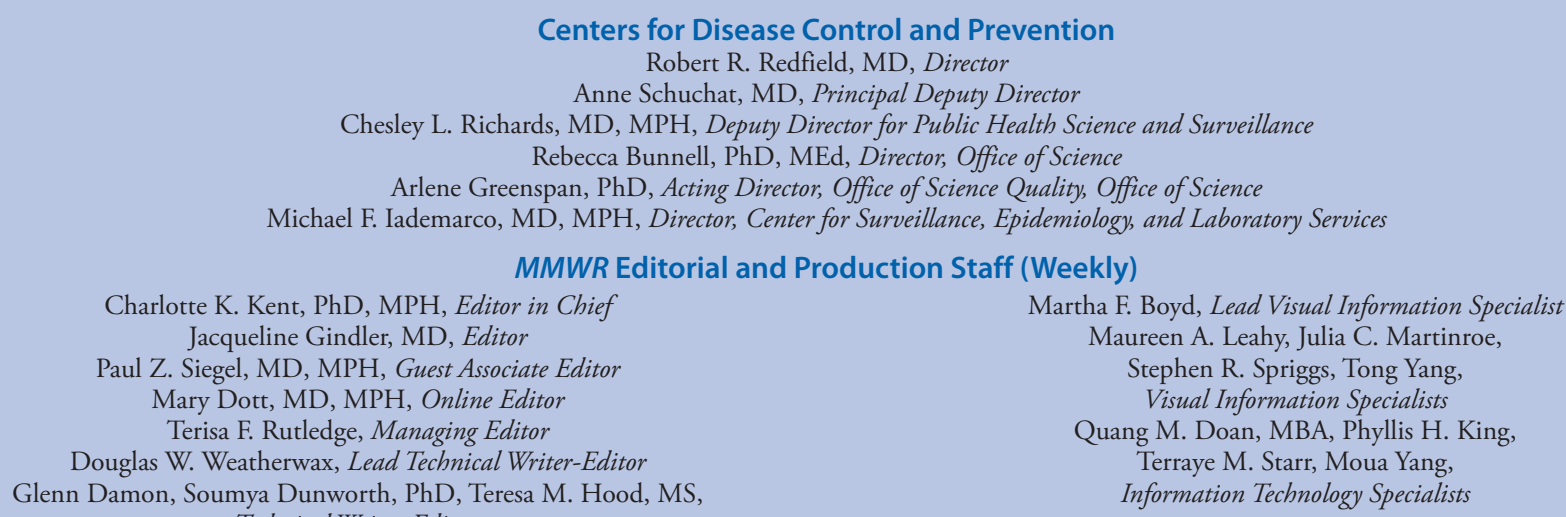

Charlotte K. Kent, PhD, MPH, Editor in Chief Jacqueline Gindler, MD, Editor

Paul Z. Siegel, MD, MPH, Guest Associate Editor

Mary Dott, MD, MPH, Online Editor

Terisa F. Rutledge, Managing Editor

Douglas W. Weatherwax, Lead Technical Writer-Editor

Glenn Damon, Soumya Dunworth, PhD, Teresa M. Hood, MS,

Martha F. Boyd, Lead Visual Information Specialist Maureen A. Leahy, Julia C. Martinroe, Stephen R. Spriggs, Tong Yang, Visual Information Specialists

Quang M. Doan, MBA, Phyllis H. King,

Terraye M. Starr, Moua Yang,

Information Technology Specialists Technical Writer-Editors

Michelle E. Bonds, MBA

Matthew L. Boulton, MD, MPH

Carolyn Brooks, ScD, MA

Jay C. Butler, MD

Virginia A. Caine, MD
MMWR Editorial Board

Timothy F. Jones, MD, Chairman

Katherine Lyon Daniel, PhD

Jonathan E. Fielding, MD, MPH, MBA

David W. Fleming, MD

William E. Halperin, MD, DrPH, MPH

Jewel Mullen, MD, MPH, MPA

Jeff Niederdeppe, PhD

\author{
Patricia Quinlisk, MD, MPH \\ Patrick L. Remington, MD, MPH \\ Carlos Roig, MS, MA \\ William Schaffner, MD \\ Morgan Bobb Swanson, BS
}


TABLE 1. Overall weighted* lifetime prevalence of work-related health problems - SummerStyles Survey, United States, 2018

\begin{tabular}{lcr}
\hline Work-related health problem & $\begin{array}{c}\text { Raw count } \\
(\mathbf{n}=\mathbf{2 , 4 2 5})^{\dagger}\end{array}$ & \multicolumn{1}{c}{$\begin{array}{c}\text { Weighted } \\
\%(95 \% \mathrm{Cl})\end{array}$} \\
\hline Any work-related health problem & 886 & $35.1(33.0-37.3)$ \\
Back pain & 488 & $19.4(17.6-21.2)$ \\
Injury that required & 385 & $14.7(13.2-16.3)$ \\
$\quad$ medical treatment & 307 & $11.5(10.1-12.9)$ \\
Injury that caused missed work & 286 & $10.9(9.5-12.2)$ \\
Other joint or muscle problem & 150 & $6.3(5.1-7.4)$ \\
Mental health problem & & \\
(e.g., depression) & 66 & $2.9(2.1-3.6)$ \\
Other health problem not listed & 61 & $2.5(1.8-3.2)$ \\
Skin condition & 49 & $2.2(1.4-2.9)$ \\
Asthma or other lung condition & 59 & $1.8(1.3-2.3)$ \\
Hearing difficulty & 18 & $0.6(0.32-0.9)$ \\
Cancer & &
\end{tabular}

Abbreviation: $\mathrm{Cl}$ = confidence interval.

* By gender, age, income, race, ethnicity, household size, education, U.S. Census region, and metro status, using U.S. Current Population Survey proportions.

${ }^{\dagger}$ Question responses were not mutually exclusive; therefore, totals do not sum to 2,425 .

significantly higher among self-employed respondents $(\mathrm{PR}=1.3 ; 95 \% \mathrm{CI}=1.1 \%-1.6 \%)$ than among part-time paid employees (referent group).

\section{Discussion}

A history of self-reported, work-related injury or illness is common in the working population; approximately one in three currently employed workers reported having experienced at least one health problem related to work during their lifetime. In this online panel survey, the prevalence of self-reported, work-related health problems varied by industry, employment situation, and certain demographic characteristics.

The current study provides the broadest published estimate of the total lifetime prevalence of occupational morbidity in the United States. This estimate is similar to findings from the 2005 European Working Conditions Survey, which estimated that an average of $35 \%$ of workers across 27 European Union countries reported that their work affected their health (7). An occupational health supplement to the 1988 National Health Interview Survey found that the overall prevalence of any of a set of 13 work-related chronic conditions was $7.5 \%$ among U.S. adults who had ever worked; however, that study did not include work-related injuries or acute illnesses and has not been repeated. Most studies focus on specific work-related health outcomes or exposures, not the overall prevalence of occupational morbidity (8). Available research on the overall occurrence of occupational morbidity typically estimates annualized incidence rates. The Bureau of Labor Statistics (BLS) reported an incidence rate of 2.8 cases per 100 full-time equivalent workers in 2018 (1). BLS estimates are based on employer reporting of certain types of injuries and illnesses. A 2019 study added to BLS estimates by combining additional resources to

\section{Summary}

What is already known about this topic?

Workers are subject to injury and illness related to their work. Current surveillance methods likely underestimate the prevalence of occupational injuries and illnesses in the population.

What is added by this report?

A history of perceived work-related injury or illness is common among the working population (35.1\%), and the prevalence varies by employment situation, industry of employment, and some demographic characteristics.

What are the implications for public health practice?

Workplace injury and illness prevention programs are needed to prevent work-related health problems, such as back pain, and reduce the number of health problems in higher-risk industries such as construction.

account for limitations in the BLS's scope and incorporating attributable fractions to estimate additional types of workrelated illnesses and injuries but was still limited to annual incidence estimates (9). The current study uniquely estimates lifetime (or cumulative) work-related morbidity and provides complementary industry and occupation-specific estimates of total nonfatal work-related health problems among currently working adults in the United States.

The findings in this report are subject to at least four limitations. First, the data are self-reported, so there is potential for recall and response bias. If a respondent developed a workrelated health problem early in their employment, they might be less likely to recall a problem compared with a respondent who either recently experienced or received a diagnosis of a health problem. Depending on how respondents view the survey, they might also be more inclined or less inclined to report that they had a work-related health problem. Second, only those persons who were currently employed were included in the study, so the results could underestimate the prevalence of occupational health problems in the entire population. Third, variance might be underestimated because no sample design variables were available from SummerStyles. Finally, there were small numbers within certain groups such as workers paid by temporary agencies, resulting in very wide confidence intervals for estimates for these subgroups.

Occupational health surveillance relies on data from a variety of sources, including employer-based reporting, public health case reporting, workers' compensation claims, health care records, and population-based surveys. All of these sources have limitations, and surveillance research is needed to determine how their use for occupational health surveillance can be improved (10). This is one of the few studies that estimates the lifetime prevalence of total work-related health problems and compares them among different industries. Although this 
TABLE 2. Weighted* prevalences and prevalence ratios of work-related health problems stratified by demographic and work characteristics SummerStyles Survey, United States, 2018

\begin{tabular}{|c|c|c|c|}
\hline Characteristic & $\begin{array}{l}\text { Raw count } \\
(n=2,425)^{\dagger}\end{array}$ & $\begin{array}{l}\text { Weighted \% of work-related } \\
\text { health problems }(95 \% \mathrm{CI})\end{array}$ & PR $(95 \% \mathrm{Cl})$ \\
\hline \multicolumn{4}{|l|}{ Sex } \\
\hline Men & 1,307 & 36.7 (33.7-39.7) & $1.1(1.0-1.2)$ \\
\hline Women & 1,118 & $33.3(30.2-36.4)$ & Referent \\
\hline \multicolumn{4}{|l|}{ Age group (yrs) } \\
\hline $18-24$ & 107 & $21.7(13.8-29.6)$ & Referent \\
\hline $25-34$ & 445 & $34.5(29.7-39.3)$ & $1.6(1.2-2.0)$ \\
\hline $35-44$ & 553 & $34.6(30.2-38.9)$ & $1.6(1.2-2.0)$ \\
\hline $45-54$ & 593 & 39.5 (35.1-43.9) & $1.8(1.4-2.3)$ \\
\hline $55-64$ & 568 & $41.3(37.0-45.6)$ & $1.9(1.5,2.4)$ \\
\hline $65-74$ & 139 & $33.0(25.0-40.9)$ & $1.5(1.1-2.1)$ \\
\hline$\geq 75$ & 20 & $29.1(8.4-49.8)$ & $1.3(0.6-3.0)$ \\
\hline \multicolumn{4}{|l|}{ Race/Ethnicity } \\
\hline White, non-Hispanic & 1,766 & $35.2(32.7-37.6)$ & $1.2(1.01 .6)$ \\
\hline Black, non-Hispanic & 218 & 39.9 (32.8-46.9) & $1.4(1.1-1.9)$ \\
\hline Other, non-Hispanic & 128 & $28.2(19.8-36.5)$ & Referent \\
\hline Hispanic & 239 & $33.8(27.2-40.4)$ & $1.2(0.9-1.6)$ \\
\hline Multiracial, non-Hispanic & 74 & $49.1(36.6-61.6)$ & $1.7(1.1-2.6)$ \\
\hline \multicolumn{4}{|l|}{ Education } \\
\hline Less than high school & 81 & $39.2(27.4-51.0)$ & $1.3(1.0-1.6)$ \\
\hline High school & 558 & $38.7(34.1-43.3)$ & $1.3(1.1-1.5)$ \\
\hline Some college & 682 & $37.3(33.2-41.3)$ & $1.2(1.1-1.4)$ \\
\hline Bachelor's degree or higher & 1,104 & $30.6(27.6-33.6)$ & Referent \\
\hline \multicolumn{4}{|l|}{ Employment situation } \\
\hline Full-time paid employee & 1,814 & $35.3(32.8-38.2)$ & $1.1(1.0-1.3)$ \\
\hline Part-time paid employee & 383 & $31.6(26.4-36.8)$ & Referent \\
\hline Self-employed & 228 & $41.2(33.9-48.4)$ & $1.3(1.1-1.6)$ \\
\hline \multicolumn{4}{|l|}{ Industry } \\
\hline Construction & 89 & $48.6(36.5-60.6)$ & $1.6(1.2-2.2)$ \\
\hline Manufacturing & 191 & $35.4(27.6-43.2)$ & $1.2(0.9-1.6)$ \\
\hline Wholesale or Retail Trade & 196 & $35.1(27.5-42.8)$ & $1.2(0.9-1.5)$ \\
\hline Education & 285 & $29.8(23.9-35.7)$ & Referent \\
\hline Food service & 127 & $38.3(28.7-47.9)$ & $1.3(1.0-1.7)$ \\
\hline Public Safety & 68 & $43.3(30.1-56.6)$ & $1.5(1.1-2.0)$ \\
\hline Service, excluding Public Safety or Food & 278 & $38.9(32.4-45.4)$ & $1.3(1.0-1.7)$ \\
\hline Mining, Oil or Gas Extraction and Agriculture, Forestry, or Fishing & 64 & $40.6(25.9-55.2)$ & $1.4(1.0-1.9)$ \\
\hline Transportation, Warehousing or Utilities & 112 & $39.1(28.7-49.5)$ & $1.3(1.0-1.8)$ \\
\hline Other sector/None of the above & 662 & $29.0(25.1-32.9)$ & $1.0(0.8-1.2)$ \\
\hline Social assistance and Healthcare & 352 & $39.4(33.7-45.2)$ & $1.3(1.1,1.7)$ \\
\hline \multicolumn{4}{|l|}{ Occupation } \\
\hline Manager & 444 & $38.7(33.5-43.8)$ & $1.3(1.0-1.6)$ \\
\hline Professional & 793 & $32.6(28.9-36.3)$ & $1.1(0.8-1.3)$ \\
\hline Community/Social Service & 78 & $38.6(26.0-51.3)$ & $0.9(0.7-1.0)$ \\
\hline Services & 358 & $38.2(32.4-44.0)$ & $1.2(1.0-1.6)$ \\
\hline Sales & 181 & $30.8(23.2-38.4)$ & Referent \\
\hline Production and related & 152 & $37.5(28.9-46.1)$ & $1.2(0.9-1.6)$ \\
\hline Other/None of the above & 416 & $34.0(28.8-39.2)$ & $1.1(0.9-1.4)$ \\
\hline \multicolumn{4}{|l|}{ Work arrangement } \\
\hline Independent contractor, independent consultant, or freelance worker & 223 & $41.9(34.6-49.2)$ & $1.3(1.01 .8)$ \\
\hline Paid by a temporary agency & 35 & $37.5(18.8-56.1)$ & $1.2(0.8-1.8)$ \\
\hline Work for a contractor who provides workers and services to others under contract & 77 & $39.1(26.6-51.6)$ & $1.2(0.9-1.7)$ \\
\hline Regular, permanent employee (standard work arrangement) & 1,953 & $34.4(32.1-36.8)$ & $1.1(0.8-1.4)$ \\
\hline Some other work arrangement & 134 & $31.8(22.7-40.9)$ & Referent \\
\hline
\end{tabular}

Abbreviations: $\mathrm{Cl}$ = confidence interval; $\mathrm{PR}=$ prevalence ratio.

* By gender, age, income, race, ethnicity, household size, education, U.S. Census region, and metro status, using U.S. Current Population Survey proportions.

† Some categories do not sum to the total because of missing values. 
study provides new information, more could be done to measure occupational morbidity. Studies using samples weighted specifically to be representative of industry and occupation groups and larger sample sizes are needed to more accurately represent the distribution of work-related health problems. Because respondents who left the workforce because of a workrelated health problem, retirement, family commitments, or other reasons were not captured by this analysis, these results are still not capturing the entirety of work-related illnesses and injuries in the United States. Work-related health problems likely represent a public health problem that is larger than is assumed because of lack of information. Workplace prevention programs should be considered to decrease work-related health problems, especially in the higher prevalence industries of Construction, Public Safety, Service (excluding Public Safety and Food), and Social Assistance and Healthcare.

\section{Acknowledgment}

Jia Li, Division of Field Studies and Engineering, National Institute for Occupational Safety and Health, CDC.

Corresponding author: Hannah Free, ooi4@cdc.gov, 513-841-4358.

${ }^{1}$ Division of Field Studies and Engineering, National Institute for Occupational Safety and Health, CDC.

All authors have completed and submitted the International Committee of Medical Journal Editors form for disclosure of potential conflicts of interest. No potential conflicts of interest were disclosed.

\section{References}

1. Bureau of Labor Statistics. Economic news release. Employer-reported workplace injury and illnesses. Washington, DC: US Department of Labor, Bureau of Labor Statistics; 2018. https://www.bls.gov/news. release/osh.nr0.htm

2. Rosenman KD, Kalush A, Reilly MJ, Gardiner JC, Reeves M, Luo Z. How much work-related injury and illness is missed by the current national surveillance system? J Occup Environ Med 2006;48:357-65. https://doi.org/10.1097/01.jom.0000205864.81970.63

3. Boden LI, Ozonoff A. Capture-recapture estimates of nonfatal workplace injuries and illnesses. Ann Epidemiol 2008;18:500-6. https://doi. org/10.1016/j.annepidem.2007.11.003

4. Tucker S, Diekrager D, Turner N, Kelloway EK. Work-related injury underreporting among young workers: prevalence, gender differences, and explanations for underreporting. J Safety Res 2014;50:67-73. https://doi.org/10.1016/j.jsr.2014.04.001

5. Kobau R, Sniezek J, Zack MM, Lucas RE, Burns A. Well-being assessment: an evaluation of well-being scales for public health and population estimates of well-being among US adults. Appl Psychol Health Well-Being 2010;2:272-97. https://doi.org/10.1111/j.1758-0854.2010.01035.x

6. Pollard WE. Use of consumer panel survey data for public health communication planning: an evaluation of survey results. In: American Statistical Association 2002: proceedings of the section on health policy statistics; Aug 11, 2002. Alexandria, VA: American Statistical Association; 2002:2720-4.

7. European Foundation for the Improvement of Living and Working Conditions. Fourth European working conditions survey 2005. Dublin, Ireland: European Foundation for the Improvement of Living and Working Conditions; 2007. https://www.eurofound.europa.eu/surveys/ european-working-conditions-surveys/fourth-european-workingconditions-survey-2005/ewcs-2005-individual-chapters

8. Luckhaupt SE, Calvert GM. Work-relatedness of selected chronic medical conditions and workers' compensation utilization: National Health Interview Survey occupational health supplement data. Am J Ind Med 2010;53:1252-63. https://doi.org/10.1002/ajim.20885

9. Groenewold M, Brown L, Smith E, Haring Sweeney M, Pana-Cryan R, Schnorr T. Burden of occupational morbidity from selected causes in the United States overall and by NORA industry sector, 2012: a conservative estimate. Am J Ind Med 2019;62:1117-34. https://doi. org/10.1002/ajim.23048

10. Souza K, Steege AL, Baron SL. Surveillance of occupational health disparities: challenges and opportunities. Am J Ind Med 2010;53:84-94. https://doi.org/10.1002/ajim.20777 